\title{
A review of the Haplodrassus montanus-group (Aranei: Gnaphosidae) in the East Palaearctic and preliminary grouping of the genus
}

\section{Обзор группы видов Haplodrassus montanus (Aranei: Gnaphosidae) из Восточной Палеарктики и предварительное группирование видов РОда}

\author{
Mikhail M. Omelko ${ }^{1,2}$, Yuri M. Marusik ${ }^{3,4}$ \\ М.М. Омелько ${ }^{1,2}$, Ю.М. Марусик ${ }^{3,4}$
}

\footnotetext{
${ }^{1}$ Gornotaezhnaya Station FEB RAS, Gornotaezhnoe Vil., Ussuriysk Dist., Primorski Krai 692533 Russia. E-mail: omelkom@gmail.com

${ }^{2}$ Far Eastern Federal University, Sukhanova 8, Vladivostok 690950 Russia.

${ }^{3}$ Institute for Biological Problems of the North, Portovaya Str. 18, Magadan 685000 Russia. E-mail: yurmar@mail.ru

${ }^{4}$ Zoological Museum, University of Turku, FI-20014 Turku, Finland.

${ }^{1}$ Горнотаёжная станция им. В.Л. Комарова ДВО РАН, с. Горнотаёжное, Уссурийский район, Приморский край 692533, Россия. Еmail: omelkom@gmail.com

2 Дальневосточный Федеральный университет, Суханова 8, Владивосток, 690950, Россия.

${ }^{3}$ Институт биологических проблем Севера, Портовая 18, Магадан, Россия. E-mail: yurmar@mail.ru

${ }^{4}$ Зоологический Музей, Университет г. Турку, FI-20014, Турку, Финляндия.
}

KEY WORDS: Araneae, Russia, China, Korea, Japan, Haplodrassus, Maritime Province.

КЛЮЧЕВЫЕ СЛОВА: Araneae, Китай, Корея, Япония, Haplodrassus, Приморский край.

ABSTRACT. A preliminary grouping of Haplodrassus Chamberlin, 1922 is proposed and nine species groups are diagnosed. Three species, Haplodrassus dentatus Xu et Song, 1987, H. hatsushibai Kamura, 2007 and H. montanus Paik et Sohn, 1984 belonging to the montanus-group are revised and diagnostic key is provided. This species group is restricted to Far East Asia. Haplodrassus montanus previously known from Korea was found in Russia (Maritime Province) for the first time.

РЕЗЮМЕ. Предложено предварительное группирование видов Haplodrassus Chamberlin, 1922. Выделено девять групп видов. Ревизованы три вида, принадлежащие к группе видов montanus: H.dentatus Xu et Song, 1987, H. hatsushibai Kamura, 2007 и H. montanus Paik et Sohn, 1984, для них приведён определительный ключ. Эта группа видов ограничена в распространении только Дальним Востоком Азии. Haplodrassus montanus ранее известный только из Кореи был впервые обнаружен в России (Приморский край).

\section{Introduction}

Haplodrassus Chamberlin, 1922 is a comparatively large genus of ground spiders with 61 species and 4 subspecies distributed in the Holarctic and India [Platnick, 2012]. Most species of the genus occur in the Palaearctic and only 7 are known from the Nearctic
[Platnick, 2012]. Of 20 species occurring in the former Soviet Union, only two, H. hiemalis (Emerton, 1909) and $H$. taepaikensis Paik, 1992, have been reported from the southern part of the Russian Far East [Mikhailov, 1997; Marusik et al., 2007]. The genus has never been revised in Russia on a broad scale. There are only two regional revisions [Ovtsharenko \& Marusik, 1988; Marusik \& Logunov, 1995] and a few papers dealing with the descriptions of new species [Marusik et al., 1996; Ponomarev \& Tsvetkov, 2006] or redescriptions of poorly known species [Tuneva \& Esyunin, 2003; Marusik et al., 2007; Piterkina \& Ovtsharenko, 2007, etc.]. The genus has been comparatively well studied in Japan [Kamura, 1995, 2007, 2009], China [Song et al., 1999, 2004] and Korea [Paik \& Sohn, 1984; Paik, 1992; Namkung, 2003].

A study of material from Maritime Province, Russia revealed one species belonging to the montanusgroup. It was impossible to place it in any known species, because the montanus-group has never been revised. Three species were known from three different countries (Korea, China and Japan) and the diagnostic figures were made in different styles, which made comparing the three species difficult. In addition, members of this group had not previously been found in Russia. In order to determine whether our specimens belonged to an undescribed species or one of the known species we decided to revise the group. Our study revealed that the specimens from Maritime Province belonged to $H$. montanus, a species known previously only from the 
Korean Peninsula. The main goals of our paper are as follows: 1) to make a preliminary grouping of Haplodrassus; 2) to define the montanus-group; 3) to provide a key to all three species of the montanus-group; 4) to provide detailed illustrations and redescriptions of the three species in the montanus-group.

\section{Material and methods}

Specimens were photographed using an Olympus Camedia E-520 camera attached to an Olympus SZX16 stereomicroscope. The images were montaged using "CombineZP" image stacking software. Photographs were taken in dishes of different sizes with paraffin in the bottom. Different-sized holes were made in the paraffin to keep the specimens in the correct position. Figures of $H$. dentatus, holotype male and paratype female stored in the Zoological Institute of the Chinese Academy of Sciences, Beijing were made by Shuqiang Li.

The specimens treated here are deposited in the two following museums: IZCAS - Institute of Zoology, Chinese Academy of Sciences; ZMMU - Zoological Museum of Moscow State University.

All measurements are in $\mathrm{mm}$.

\section{Haplodrassus Chamberlin, 1922}

Type species: Drassus hiemalis Emerton, 1909.

COMMENTS. This genus has never been subdivided into subgenera or species groups, even though it encompasses 65 taxa. Like many species-rich genera, Haplodrassus can be split into a few easily delimited species groups or to many species groups without clear limits, including mono-specific groups. Although the main goal of this paper is to revise three closely related species, we decided to propose preliminary species groups within the genus, based mainly on the shape of the male palp. Some comments on the terminology used for describing the male palp are required. All authors [Platnick \& Shadab, 1975; Marusik \& Logunov, 1995; Levy, 2004; Piterkina \& Ovtsharenko, 2007; Kovblyuk et al., 2012, etc.] use the term terminal apophysis for the apophysis emerging from the base of the embolus, which is located in the center of the bulbus (Figs 1, 7, 10, 13). The median apophysis also has a terminal (retrolateral) position (Figs 1, 9, 12, 15). Here, we prefer to use the term embolic apophysis, just to indicate the origin of this structure. In some species, such as H. hiemalis (Fig. 25), H. signifer (C.L. Koch, 1839) (Fig. 26) and H. mediterraneus Levy, 2004 it is very clear that the terminal apophysis belongs to the embolic division. It is especially clearly visible in $H$. tegulatus (Schenkel, 1963). However, in several species the embolic division is almost $[H$. minor (O. PickardCambridge, 1879), Fig. 27] or totally fused (Figs 1-2, 7-8, 10-11, 13-14, 28).

\section{Species grouping}

Several species either known by one sex or poorly described are not placed in a specific group.

\section{Haplodrassus signifier-group}

This group can be easily diagnosed by the straight or turned embolic apophysis lacking any processes. The embolic apophysis is subequal in width to the embolus and not concealed by it. In some species the embolic division is well separated from the tegulum (Fig. 26), while in another the embolic division is almost fused with the tegulum (Fig. 27).

COMPOSITION: H. aenus Thaler, 1984; H. atarot Levy, 2004; H. bohemicus Miller et Buchar, 1977; $H$. chamberlini Platnick et Shadab, 1975; H. concertor (Simon, 1878); H. deserticola Schmidt et Krause, 1996 (?); H. dixiensis Chamberlin et Woodbury, 1929; H. invalidus (O. Pickard-Cambridge, 1872); H. lilliputanus Levy, 2004; H. macellinus (Thorell, 1871); H. maculatus (Banks, 1904); H. mimus Chamberlin, 1922; H. minor (O. Pickard-Cambridge, 1879); H. morosus (O. Pickard-Cambridge, 1872) (?); H. ovtchinnikovi Ponomarev, 2008; H. pargongsanensis Paik, 1992 (possible synonym of $H$. pugnans); H. pseudosignifer Marusik, Hippa et Koponen, 1996; H. pugnans (Simon, 1880); H. signifer (C.L. Koch, 1839); H. taibo (Chamberlin, 1919); $H$. vastus (Hu, 1989) (possible synonym of $H$. pugnans).

\section{Haplodrassus dalmatensis-group}

This species group resembles the signifier-group, but the embolic apophysis lacks a ridge or furrow and has a small spine.

COMPOSITION: H. dalmatensis (L. Koch, 1866); H. isaevi Ponomarev et Tsvetkov, 2006; H. severus (C.L. Koch, 1839).

\section{Haplodrassus umbratilis-group}

This is an easily diagnosed group based on the flat outgrowth of the embolic apophysis.

COMPOSITION: $H$. belgeri Ovtsharenko et Marusik, 1988; H. eunis Chamberlin, 1922; H. rugosus Tuneva, 2005; H. soerenseni (Strand, 1900); H. umbratilis (L. Koch, 1866).

\section{Haplodrassus kulczynskii-group}

This group can be distinguished by the embolic apophysis being widened to the top (Fig. 28) and in carrying spines or triangular lobes. The embolic apophysis is directed upward-retrolaterally.

COMPOSITION: H. kulczynskii Lohmander, 1942; H. taepaikensis Paik, 1992.

\section{Haplodrassus silvestris-group}

This group can be distinguished by the wide embolic apophysis that hides the embolus (Fig. 25). The apophysis lacks outgrowths and is wider distally.

COMPOSITION: H. cognatus (Westring, 1861); H. creticus (Roewer, 1928); H. hiemalis (Emerton, 1909); H. kanenoi Kamura, 1995; H. moderatus (Kul- 

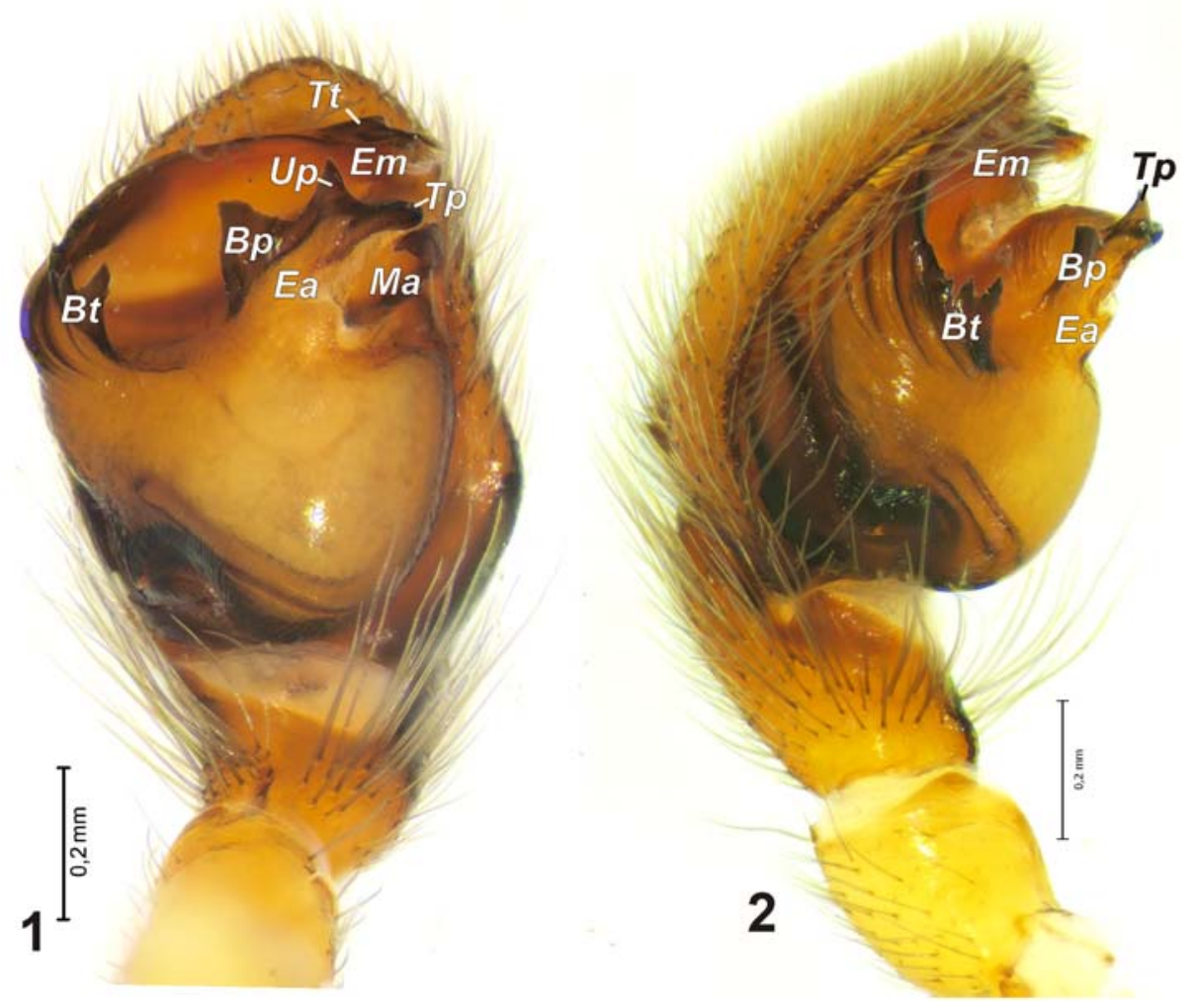

Figs 1-2. Male palp of Haplodrassus montanus: 1 - ventral view; 2 - prolateral view. Abbreviations: $B p$ - basal process; $B t-$ basal tooth; $E a$ - embolic apophysis; $E m$ - embolus; $M a$ - median apophysis; $T p$ - terminal process; $T t$ - terminal tooth; $U p$ - upper process.

Рис. 1-2. Пальпа самца Haplodrassus montanus: 1 - вентрально; 2 - пролатерально. Сокращения: $B p$ - базальный отросток; $B t$ - базальный зубец; $E a$ - отросток эмболюса; $E m$ - эмболюс; $M a$ - медиальный отросток; $T p$ - терминальный отросток; $T t$ - терминальный зубец; $U p$ - верхний отросток.

czyński, 1897); H. paramecus Zhang, Song et Zhu, 2001; H. ponomarevi Kovblyuk et Seyyar, 2009; H. silvestris (Blackwall, 1833).

\section{Haplodrassus mediterraneus-group}

This monotypic group has a strongly reduced embolic apophysis, which gradually tapers.

COMPOSITION: H. mediterraneus Levy, 2004.

\section{Haplodrassus tegulatus-group}

This monotypic group can be easily recognized by the strongly reduced embolic apophysis, thin embolus (Fig. 29); gradually tapering tibial apophysis; heavily sclerotized apical pocket of the epigyne with a distinct hood. Tuvadrassus Marusik et Logunov, 1995 was described for this species, but Murphy [2007] considered Tuvadrassus as a synonym of Haplodrassus.

COMPOSITION: H. tegulatus (Schenkel, 1963).

\section{Haplodrassus caspius-group}

Although this monotypic group was previously based on female characters, we had the opportunity to study the male of $H$. caspius Ponomarev et Belosludtsev,
2008. Unique for this genus, it has a droplet-shaped cymbium, sharply pointed tibial apophysis, and the tip of the embolus has a hook [Kovblyuk et al., 2013].

COMPOSITION: H. caspius Ponomarev et Belosludtsev, 2008.

\section{Haplodrassus montanus-group}

This group can be distinguished by having spines (teeth) on the tibial apophysis (Figs 16-19), a wide (in prolateral view) trilobate embolic apophysis and a long embolus. In comparison to other species groups it has the widest bulbus: width of bulbus measured near the base of the embolus exceeds the height of the terminal part of the bulbus (embolic division).

COMPOSITION: H. dentatus Xu et Song, 1987; H. montanus Paik et Sohn, 1984; H. hatsushibai Kamura, 2007.

DISTINGUISHING THE SPECIES. Species of this group can be separated by the following characters: number of teeth on the tibial apophysis; outline of tip of tibial apophysis; shape of the embolic apophysis; shape of the processes of the embolic apophysis; presence or absence of a basal tooth on the embolus and its shape; length and width of the embolus; shape of the receptacles, septum and inner margin of the fovea. 

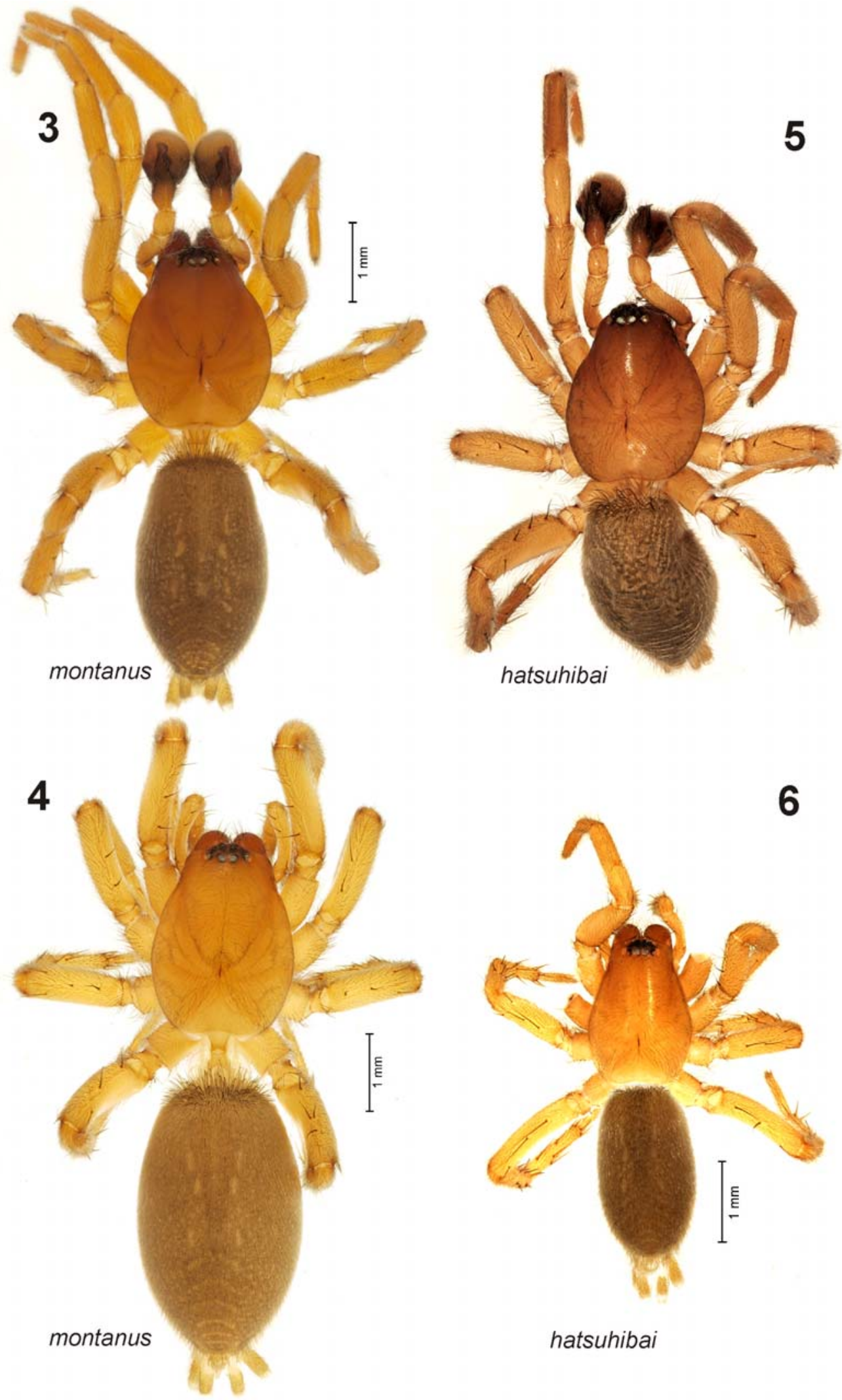

Figs 3-6. Habitus of Haplodrassus montanus (3-4) and H. hatsushibai (5-6): 3, 5- males; 4, 6 - females. Рис. 3-6. Внешний вид Haplodrassus montanus (3-4) и H. hatsushibai (5-6): 3, 5 - самцы; 4, 6 - самки. 

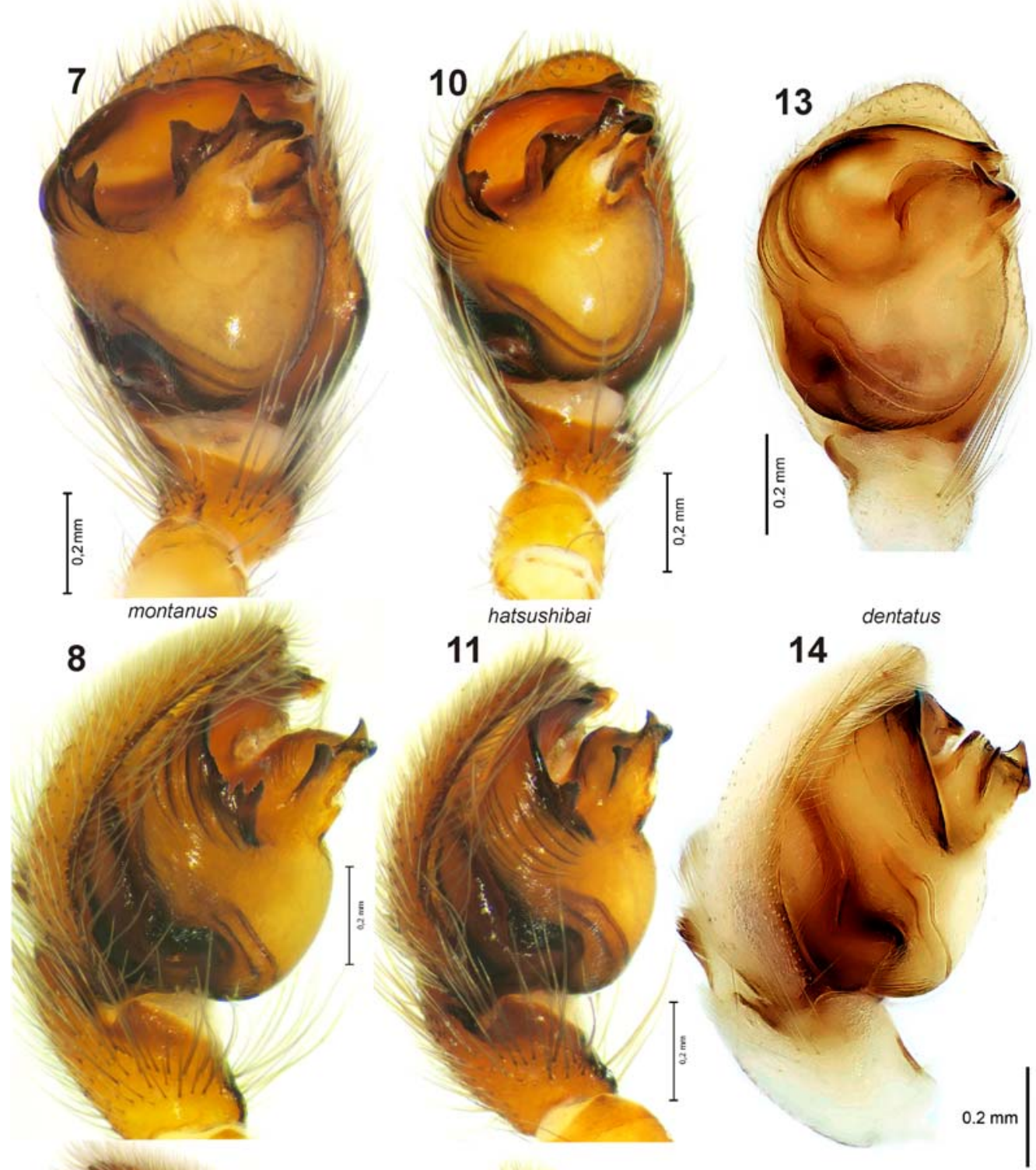

\section{1}

14
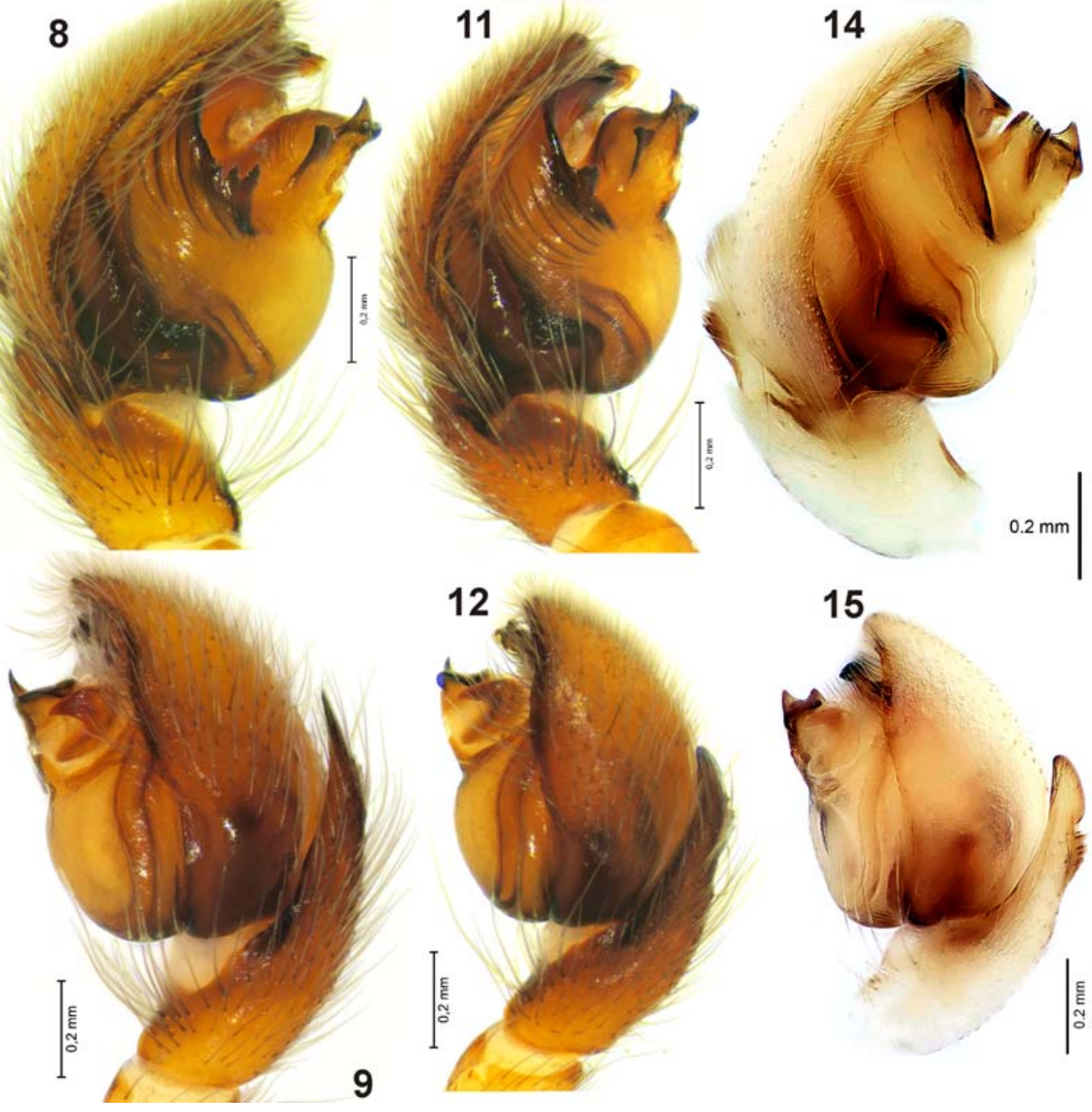

12
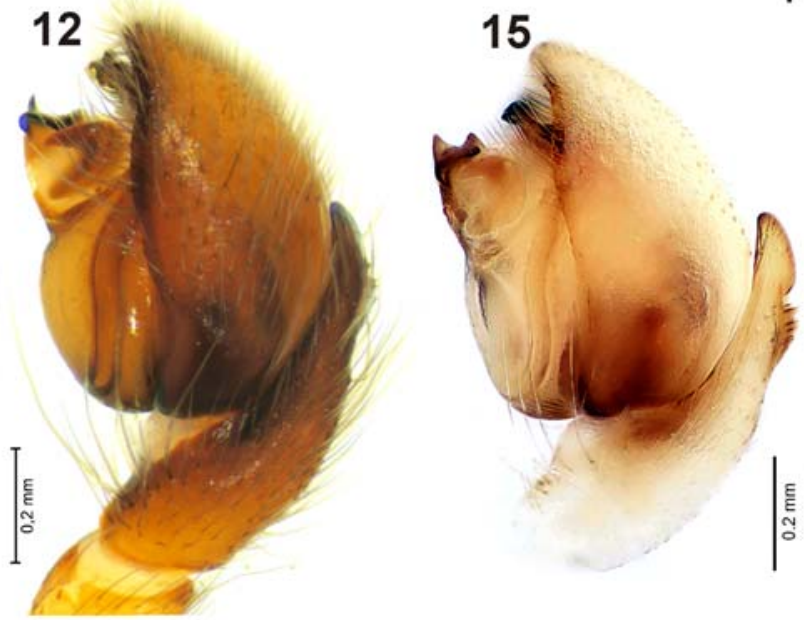

Figs 7-15. Male palp of Haplodrassus montanus (7-9), H. hatsushibai (10-12) and H. dentatus (13-15): 7, 10, 13 — ventral view; 8, 11,14 - prolateral view; 9, 12, 15 - retrolateral view.

Рис. 7-15. Пальпа самца Haplodrassus montanus (7-9), H. hatsushibai (10-12) и H. dentatus (13-15): 7, 10, 13 — вентрально; 8, 11,14 - пролатерально; 9, 12, 15 - ретролатерально. 

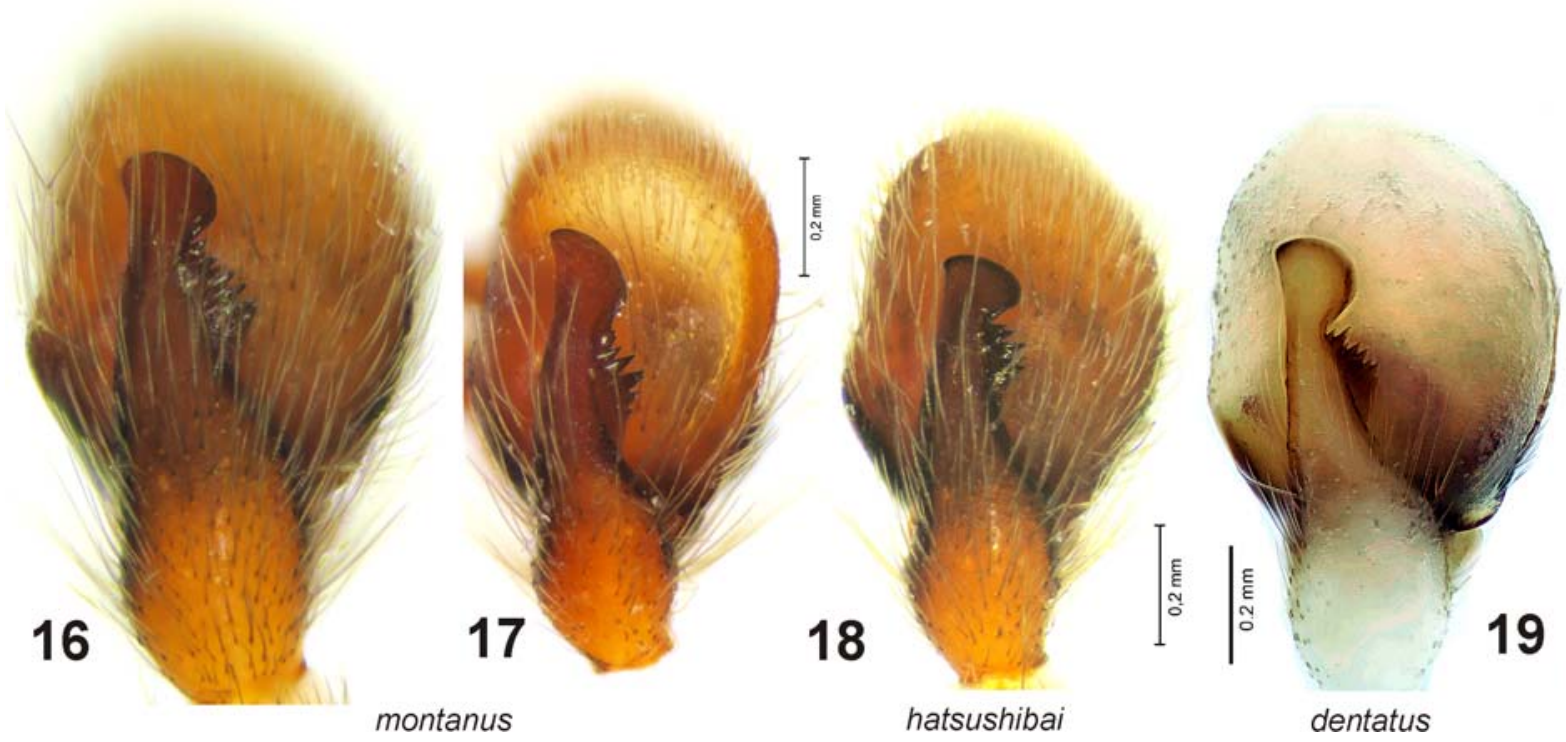

Figs 16-19. Male palp of Haplodrassus montanus (16, 17), H. hatsushibai (18) and H. dentatus (19), dorsal view. Рис. 16-19. Пальпа самца Haplodrassus montanus (16, 17), H. hatsushibai (18) и H. dentatus (19), дорсально.

\section{KEY TO THE HAPLODRASSUS MONTANUS-GROUP}

1. Male

- Female

. Base of embolus without tooth or teeth, processes of embolic apophysis not triangular (Fig. 13)

H. dentatus

- Base of embolus either with one serrated tooth or with 1-2 large teeth, embolic apophysis with two large triangular processes visible in ventral view (Figs $7,8,10,11) \ldots .3$

3. Upper process of embolic apophysis small; distance between base of embolus and base of embolic apophysis about $1 / 5$ of bulbus width; base of embolus noticeably prominent with 5-6 ridges (visible in retrolateral view); most teeth on RTA located in upper part of apophysis (Figs 10-12, 18) H. hatsushibai

- Upper process of embolic apophysis long, distance between base of embolus and base of embolic apophysis approximately $1 / 4$ of bulbus width; base of embolus is slightly prominent and has 3-4 ridges (visible in retrolateral position); most teeth on RTA located in middle part of apophysis or along its full length (Figs 7$9,16,17)$. H. montanus

4. Receptacles oval, septum poorly developed, with parallel margins (Fig. 25) .... H. dentatus

- Receptacles as long as wide (Figs 22,24) ..................... 5

5. Septum narrowing anteriorly (Fig. 20) ....... H. montanus

- Septum narrowing posteriorly (Fig. 23) ... H. hatsushibai

\section{Survey of species}

Haplodrassus dentatus Xu et Song, 1987 Figs 13-15, 19, 25.

H. d. Xu \& Song, 1987: 83, f. 1-4 (ठㅇ).

H. $d .: \mathrm{Xu}, 1991: 37$, f. 15 ( $(+)$.

$H$. $d$.: Song et al., 1999: 451, f. 263B, J ( $\left.\sigma^{7}+\right)$.

H. d.: Song et al., 2004: 132, f. 77A-D ( $\left.\sigma^{7}+\right)$.
MATERIAL EXAMINED. Holotype $\sigma^{\top}$ and allotype $q$ from Guniujiang Natural Reserve, Anhui Province, 900 m, 8.07.1983 (Y.J. Xu, L. Wang) in IZCAS. Digital figures made by S. Li.

DIAGNOSIS. Males of $H$. dentatus differ from other species of this group by the absence of teeth (or a tooth) on the base of the embolus, a comparatively short tegular apophysis and a small median apophysis. Males of this species can also be recognized by the shape of the tip of the tibial apophysis, which is almost half-round (Fig. 19). Females of this species can easily be distinguished from $H$. hatsushibai by the shape of the septum and their large receptacles.

DESCRIPTION (measurements after Song et al. [2004]). Male. Total length 4.2; carapace 1.95 long and 1.58 wide. General coloration light brown, abdomen without pattern. Palp as in Figs 13-15, 19. Tip of tibial apophysis semi-round. Median apophysis almost invisible in ventral view, hidden by embolic apophysis; embolic apophysis wider than tall, with small upper tooth, basal tooth undeveloped; embolus long and broad, without basal tooth and with small terminal tooth.

Female. Total length 4.1, carapace 1.94 long, 1.45 wide. Coloration as in male. Epigyne as in Fig. 25. Fovea without distinct septum, macerated epigyne has septum with parallel margins; receptacles large, oval-shaped.

DISTRIBUTION. It is known only from the type locality, Anhui Province of China (Fig. 30).

Haplodrassus hatsushibai Kamura, 2007

Figs 5-6, 10-12, 18, 23-24,

H. montanus: Chikuni 1989: 121, f. 17 (○フㅇ, misidentified).

H. h. Kamura, 2007: 100, f. 23-31 ( $\left.\sigma^{7}+\right)$.

H. h.: Kamura, 2009: 487, f. 43-45 ( ( 7 \%).

MATERIAL EXAMINED. JAPAN: $10^{7} 19$ (ZMMU), Yaho, Kunitachi-shi, Tokyo, 21.03.2007 (S. Hatsushiba). 

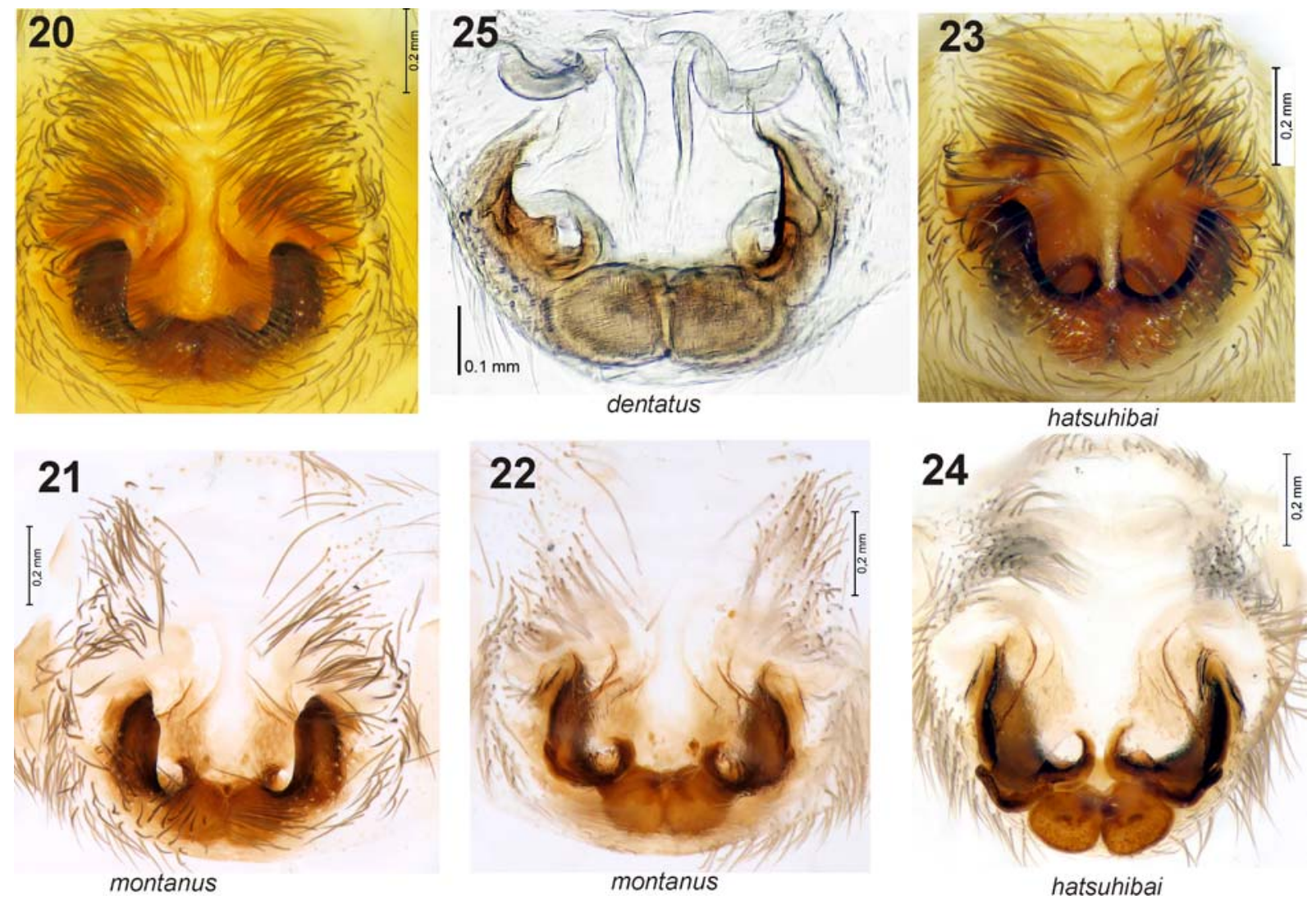

Figs 20-24. Epigynes of Haplodrassus montanus (20-22), H. hatsushibai (23-24) and H. dentatus (25): 20, 21, 23 - ventral view, 22, 24, 25 -view dorsal.

Рис. 20-24. Эпигины Haplodrassus montanus (20-22), H. hatsushibai (23-24) и H. dentatus (25): 20, 21, 23 — вентрально, 22, 24, 25 - дорсально.

DIAGNOSIS. Haplodrassus hatsushibai is very similar to H. montanus. Males of these species can be distinguished by the less developed upper process of the embolic apophysis in H. hatsushibai, and the less prominent base of the embolus. From $H$. denatatus it can be easily separated by having a basal tooth on the embolus (lacking in H. dentatus) and three well developed processes of the embolic apophysis (only one in $H$. dentatus). Females of $H$. montanus can be distinguished from $H$. hatsushibai by the shape of the septum, which is widened anteriorly (narrowing anteriorly in $H$. dentatus). The inner margins of the epigynal pockets diverge slightly in $H$. hatsushibai and are subparallel in $H$. dentatus.

DESCRIPTION (measurements after Kamura [2007]). Male. Total length 4.23, carapace 2.0 long, 1.58 wide. General coloration brownish (Fig. 5). Carapace without any pattern, somewhat lighter than abdomen. Legs brownish, metatarsi I darker than other segments. Palps brownish, RTA and base of cymbium dark brown. Palp as in Figs 10-12. Retrolateral tibial apophysis with five spines fused at the base, tip of apophysis oval-shaped on mesal side. Embolic apophysis with three well developed processes; basal and upper processes well separated, basal process triangular, twice as wide as it is tall, upper process not sharply pointed; embolus with triangle-shaped basal tooth and a small terminal tooth.

Female. Total length 4.43, carapace 1.9 long, 1.38 wide. General coloration as in male, but somewhat lighter (Fig 6). Epigyne as in Figs 23-24. Margins of fovea diverging, septum well developed, widening anteriorly; receptacles as long as wide.

DISTRIBUTION AND COMMENTS. So far it is known from Honshu (environs of Tokyo) and Hokkaido (SSE shore) only (Fig. 30). Judging from the figures of the male palp provided by Kamura [2007] for specimens from Hokkaido [cf. Kamura, 2007: Figs 30-31], the Hokkaido population may belong to a separate species. Males from this population have a smaller embolus (less protruding prolaterally), the embolic basal tooth is not triangle-shaped but represented by a series of denticles. There are differences in the basal process of the embolic apophysis.

Haplodrassus montanus Paik et Sohn, 1984 Figs 1-4, 7-9, 16-17, 20-22.

H. m. Paik \& Sohn, 1984: 107, f. 14-26 ( (

H. $m$.: Namkung, 2002: 470, f. 37.11a-b ( $\left.\sigma^{7} 9\right)$.

H. $m$.: Namkung, 2003: 473, f. 37.11a-b $\left(\sigma^{7}+\right)$

H. $m$.: Jung et al., 2005: 182, f. 65, 128 ( $\sigma^{7}+$ ).

MATERIAL EXAMINED. RUSSIA, Maritime Province: $310^{7} \sigma^{7} 9$ 9 + (ZMMU), Ussuriysk Dist., Gornotaezhnaya station, 

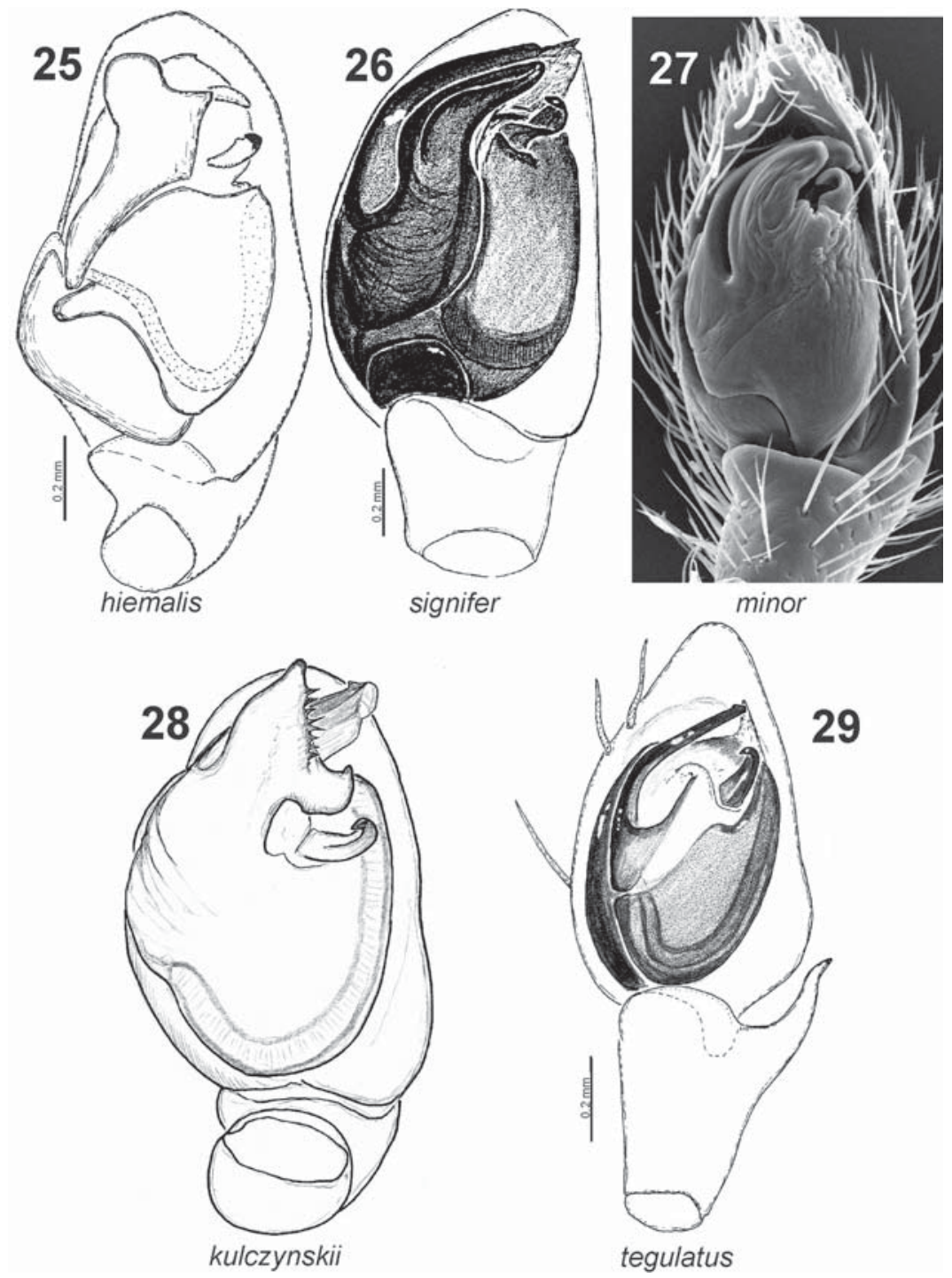

Figs 25-29. Ventral view of male palp of Haplodrassus hiemalis (25), H. signifier (26), H. minor (27), H. kulczynskii (28) and H. tegulatus (30): 25, 30 — after Marusik \& Logunov [1995], 26 — after Marusik et al. [1996].

Рис. 25-29. Вентральный вид пальпы самца Haplodrassus hiemalis (25), H. signifier (26), H. minor (27), H. kulczynskii (28) и H. tegulatus (30): 25, 30 — по Marusik \& Logunov [1995], 26 — по Marusik et al. [1996].

Lysaya sopka, $43^{\circ} 42^{\prime} 00^{\prime \prime} \mathrm{N}, 132^{\circ} 08^{\prime} 60^{\prime} \mathrm{E}$, April \& May 2002 \& 2003 (M.M. Omelko); $80^{7} 0^{7} 2$ ' 9 (ZMMU), Ussuriysk Dist., environs of Zarechnoe Village, $43^{\circ} 42^{\prime} 02^{\prime \prime} \mathrm{N}, 137^{\circ} 07^{\prime} 09^{\prime \prime} \mathrm{E}$, meadow, 216.05.2006 (M.M. Omelko). KOREA: $10^{7} 1$ 우 (ZMMU), Gangwon-do, Gwangmijang, Mt. Odaesan, 3749'19' 'N 128 38'19''E, 357 m, 11.07.2005 (B.W. Kim)

DIAGNOSIS. Differences between H. montanus and other species of this group are indicated in the diagnoses above.

DESCRIPTION. Male. Total length 4.90-5.90. Carapace: $2.05-2.40$ long, $1.55-1.90$ wide. Leg I segments: 1.50-1.70 femora, $0.80-1.00$ patellae, $1.20-1.45$ tibiae, 0.95-1.05 metatarsi, 0.75-0.90 tarsi. General coloration yellowish brown (Fig. 3). Abdomen somewhat darker than carapace. Abdomen with light spots on anterior half and thin lines on the posterior half. Legs and palps yellowish.

Palp as in Figs 1-2, 7-9, 16-17. Retrolateral tibial apophysis with eight spines fused together at the base.
Embolic apophysis with three well developed processes, basal process triangular, as wide as high, bases of basal and upper processes touch each other; upper process triangular, as wide as high; embolus with large serrated basal tooth and small terminal tooth.

Female. Total length 5.50-6.95. Carapace: 2.20 2.60 long, $1.60-1.95$ wide. Leg I segments: $1.30-1.75$ femora, 0.80-1.00 patellae, $1.05-1.35$ tibiae, 0.80 0.95 metatarsi, $0.55-0.90$ tarsi. Coloration as in males but lighter (Fig. 4). Epigyne as in Figs 20-22. Inner margins of fovea parallel to each other; septum narrowing anteriorly; receptacles as long as wide.

BIOLOGICAL NOTES. Most of the specimens were collected by pitfall traps in dry meadows. All adult specimens were collected in April and May.

DISTRIBUTION. South Korea and Maritime Province of Russia (Fig. 30). 


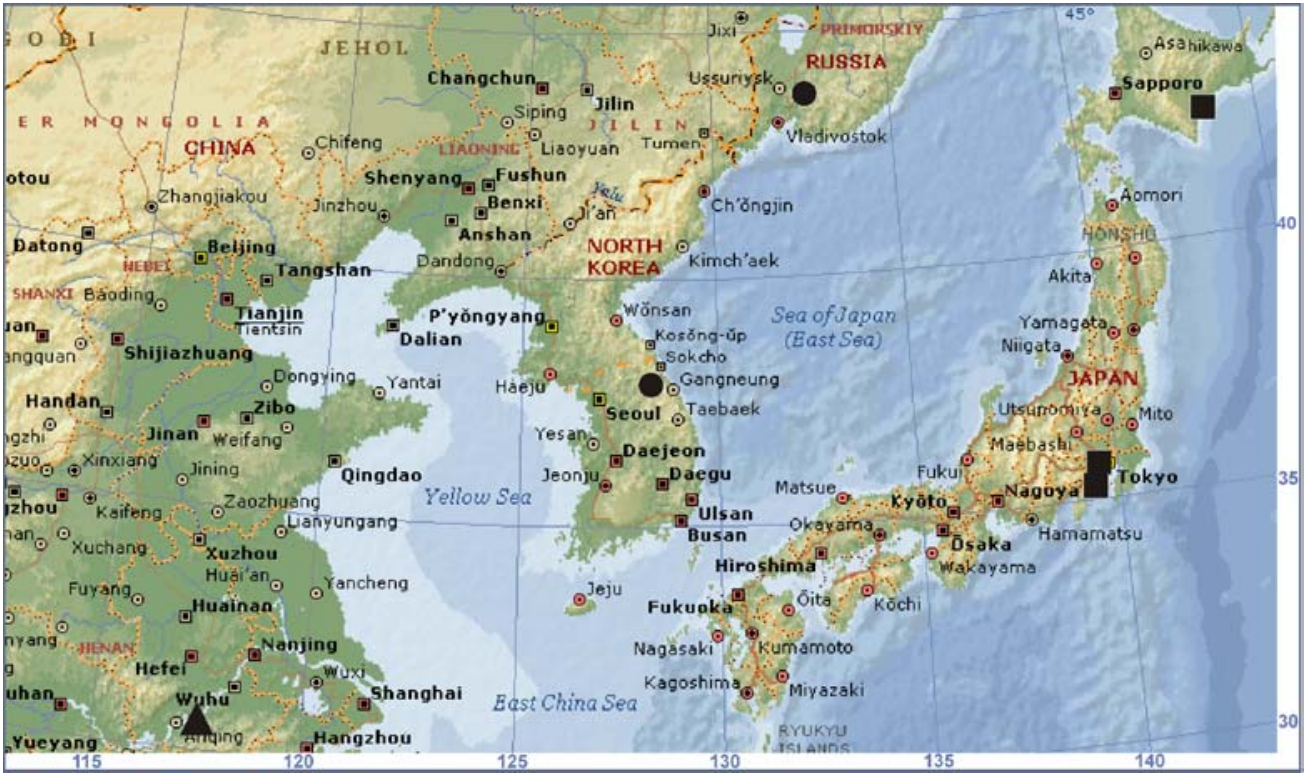

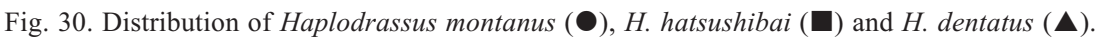

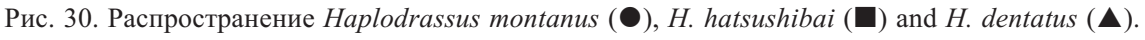

ACKNOWLEDGEMENTS. We wish to thank Seppo Koponen who arranged our stay in Turku and allowed the use of local facilities (digital camera attached to microscope). Comparative material was given to us by Takahide Kamura and Byung-Woo Kim. Shuqiang Li kindly provided us with figures of the holotype and allotype of $H$. dentatus. We thanks Mykola M. Kovblyuk and an anonymous reviewer for their comments, corrections and suggestions that improved our manuscript. The English of the final draft was kindly checked by David Penney, Manchester, UK. This project was supported in part by the Russian Foundation for Basic Research (grants \#\#11-0401716 and 12-04-01548) and the Far Eastern Federal University, Vladivostok.

\section{References}

Chikuni Y. 1989. Pictorial Encyclopedia of Spiders in Japan. Tokyo: Kaisei-sha Publ. Co. 310 pp. [in Japanese]

Jung B.G., Kim J.P., Song R.J., Jung J.W., Park Y.C. 2005. A revision of family Gnaphosidae Pocock, 1898 from Korea // Korean Arachnolology. Vol.21. No.2. P.163-233.

Kamura T. 1995. A new species and a newly recorded species of the genus Haplodrassus (Araneae: Gnaphosidae) from Japan // Acta arachnologica. Vol.44. No.2. P.123-127.

Kamura T. 2007. Spiders of the genus Haplodrassus (Araneae: Gnaphosidae) from Japan //Acta arachnologica. Vol.55. No.2. P.95-103.

Kamura T. 2009. Gnaphosidae // Ono H. (ed.). The spiders of Japan with keys to the families and genera and illustrations of the species. Kanagawa: Tokai University Press. P.483-489.

Kovblyuk M.M., Kastrygina Z.A., Omelko M.M. 2012. A review of the spider genus Haplodrassus Chamberlin, 1922 in Crimea (Ukraine) and adjacent areas (Araneae, Gnaphosidae) // ZooKeys. Vol.205. P.59-89.

Kovblyuk M.M., Kastrygina Z.A., Marusik Y.M., Omelko M.M. 2013 (in press). Redescription of Haplodrassus caspius Ponomarev et Belosludtsev, 2008 (Araneae: Gnaphosidae) with first description of the male // Zoology in the Middle East.
Levy G. 2004. Spiders of the genera Drassodes and Haplodrassus (Araneae, Gnaphosidae) from Israel // Israel Journal of Zoology. Vol.50. No.1. P.1-37.

Marusik Y.M., Hippa H., Koponen S. 1996. Spiders from the Altai area, South Siberia // Acta Zoologica Fennica. Vol.201. P.11-45.

Marusik Y.M., Logunov D.V. 1995. Gnaphosid spiders from Tuva and adjacent territories, Russia // Beiträge zur Araneologie. Bd.4. P.177-210.

Marusik Y.M., Tanasevitch A.V., Kurenshchikov D.K., Logunov D.V. 2007. A check-list of the spiders (Araneae) of the Bolshekhekhtsyrski Nature Reserve, Khabarovsk Province, the Russian Far East // Acta arachnologica sinica. Vol.16. No.1. P.3764.

Mikhailov K.G. 1997. Catalogue of the spiders of the territories of the former Soviet Union (Arachnida, Aranei). Moscow: Zoological Museum of the Moscow State University. 416 pp.

Murphy J. 2007. Gnaphosid genera of the world. St Neots, Cambs.: British Arachnological Society. Vol.1. 92 pp.

Namkung J. 2002. [The spiders of Korea]. Seoul: Kyo-Hak Publishing Co. 648 pp. [in Korean]

Namkung J. 2003. [The Spiders of Korea]. 2nd. ed. Seoul: KyoHak Publ. Co. 648 pp. [in Korean]

Ovtsharenko V.I., Marusik Y.M. 1988. [Spiders of the family Gnaphosidae (Aranei) of the north-east of the USSR (the Magadan Province)] // Entomologicheskoe obozrenie. T.67. No.1. P.204217 [in Russian].

Paik K.Y. 1992. Korean spiders of the genus Haplodrassus (Araneae: Gnaphosidae) II // Korean Arachnology. Vol.8. No.1-2. P.85-93.

Paik K.Y., Sohn S.R. 1984. The Korean spiders of the genus Haplodrassus Chamberlin, 1922 (Araneae: Gnaphosidae) // Journal Institute of natural Sciences. Vol.3. No.1. P.105-112.

Piterkina T.V., Ovtsharenko V.I. 2007. [Interesting findings of spiders of the families Gnaphosidae and Liocranidae (Aranei) from semi-desert of the northern Caspian lowland] // Zoologicheskii Zhurnal. T.86. Vyp.12. P.1425-1432 [in Russian].

Platnick N.I. 2012. The World Spider Catalog, Version 13.0 American Museum of Natural History, online at http://research.amnh. org/entomology/spiders/catalog/index.html 
Platnick N.I., Shadab M.U. 1975. A revision of the spider genera Haplodrassus and Orodrassus (Araneae, Gnaphosidae) in North America // American Museum Novitates. No.2583. P.1-40.

Ponomarev A.V., Tsvetkov A.S. 2006. [New and rare spiders of family Gnaphosidae (Aranei) from a southeast of Europe] // Caucasian entomological bulletin. T.2. No.1. P.5-13 [in Russian].

Song D.X., Zhu M.S., Chen J. 1999. The Spiders of China. Shijiazhuang: Hebei Science and Technology Publishing House. $640 \mathrm{pp}$.

Song D.X., Zhu M.S., Zhang F. 2004. [Arachnida: Araneae: Gnaphosidae] // Fauna Sinica: Invertebrata. Vol.39. 362 pp. [in Chinese]
Tuneva T.K., Esyunin S.L. 2003. A review of the Gnaphosidae fauna of the Urals (Aranei), 3. New species and new records, chiefly from the south Urals // Arthropoda Selecta. Vol.11. No.3. P.223-234

$\mathrm{Xu}$ Y.J. 1991. [Studies on the spiders of the family Gnaphosidae from Anhui (Part II)] // Journal Huizhou Teacher's School. No.1. P.37-41 [in Chinese].

Xu Y.J., Song D.X. 1987. A new species of the genus Haplodrassus (Araneae, Gnaphosidae) from China // Journal Anhui Normal University. No.4. P.83-85 [in Chinese].

Responsible editor S. Koponen 